імені Івана Франка. Філософські науки. 2016. Вип. 1. C. $49-53$.

5. Психологічна готовність військовослужбовців Національної гвардії України до службово-бойової діяльності поза межами пункту постійної дислокації : монографія / О. С. Колесніченко, Я. В. Мацегора, В. І. Воробйова та ін. Х. : Національна акад. НГУ, 2016. $335 \mathrm{c}$.

\section{REFERENCES}

1. Bryzhatyi, Ye. I. (2012). Porivnialnyi analiz formuvannia profesiinoi hotovnosti ofitseriv v armiiakh providnykh krain svitu [Comparative analysis of formation of professional readiness of officers in the armies of the leading countries of the world]. Collection of scientific works of the Khmelnytskiy Institute of Social Technologies of the "Ukraine" Univer. No. 5, pp. 20-25. [in Ukrainian].

2. Bekh, I. D., Kyrychenko, V. I. \& Petrochko, Zh. V. (2016). Z Ukrainoiu v sertsi (treninh z patriotychnoho vykhovannia ditei ta molodi) : posib. [With Ukraine in the heart (training on patriotic education of children and youth):manual]. Kharkiv, 140 p. [in Ukrainian].

3. Inozemtsev, T. V. (2018). Pidhotovka maibutnikh ofitseriv do vykhovnoi roboty u Zbroinykh sylakh Ukrainy [Preparation of future officers for educational work in the Armed Forces of Ukraine]. "The Young Scientist". No.10 (62), pp. 59-62. [in Ukrainian].

4. Kovtun, Yu. V. (2016). Patriotychne vykhovannia viiskovosluzhbovtsiv yak osnova stanovlennia ukrainskoi natsionalnoi elity [Patriotic education of servicemen as a basis for the formation of the Ukrainian national elite]. Bulletin of Zhytomyr State University named after Ivan Franko. Philosophical sciences. Vol. 1, pp. 49-53. [in Ukrainian].

5. Kolesnichenko, O. S., Matsehora, Ya. V. \& Vorobiova, V. I (2016). Psykholohichna hotovnist viiskovosluzhbovtsiv Natsionalnoi hvardii Ukrainy do sluzhbovo-boiovoi diialnosti poza mezhamy punktu postiinoi dyslokatsii [Psychological readiness of the servicemen of the National Guard of Ukraine to military service beyond the point of permanent disposition]. Kharkiv, 335 p. [in Ukrainian].

Стаття надійшла до редакції 04.03.2019

УДК 373.2.091.33-027.22

DOI:

Віолета Городиська, кандидат педагогічних наук, доцент кафедри загальної педагогіки та дошкільної освіти Дрогобииького державного педагогічного університету імені Івана Франка

\title{
ЗМІСТОВІ АСПЕКТИ ПІДГОТОВКИ СВЯТ ТА РОЗВАГ У ЗДО
}

У статті висвітлено зміст понять “свято” та “розвага”; розкрито мету їхньго проведення в закладах дошкільної освіти та значення для різностороннього розвитку дітей; здійснено аналіз чинних освітніх програм дошкільної освіти щуодо напрямів реалізації свят та розваг у ЗДО; акцентовано увагу на парціальних програмах “Стежина” та “Веселкова музикотерапія”, у яких найтрунтовніме представлено змістові аспекти підготовки свят і розваг у сучасних закладах дошкільної освіти.

Ключові слова: свята; розваги; естетичне виховання; художньо-естетичне виховання; музичне виховання дошкільників.

תim. 15.

Violeta Horodyska, Ph.D.(Pedagogy), Associate Professor of the General Pedagogy and Preschool Education Department, Drohobych Ivan Franko State Pedagogical University

\section{SEMANTIC ASPECTS OF PREPARATION OF HOLIDAYS AND ENTERTAINMENT FOR CHILDREN IN PRESCHOOL EDUCATION STUDIES}

The article covers the meaning of the concepts "holiday" and "entertainment"; the purpose of their conduct in the pre-school establishments and importance for the diverse development of children is revealed; the analysis of the existing educational programs of preschool education concerning directions of realization of holidays and entertainments in institutions of preschool education; The most promising educational program for this intelligence - "The Path", as well as the partial "Rainbow Music Therapy", is elaborated, in which the substantive aspects of preparation of holidays and entertainments in modern institutions of preschool education are presented in the most comprehensive way.

The attention of teachers of preschool establishments is to focus on traditional local customs, distinctive national peculiarities of musical culture, cultural-regional traditions, rituals, and adapt them to the specifics of a preschool institution.

After analyzing the software for modern pre-school establishments ("Ukrainian preschool", "Child" "Child in preschool years", "Sunflower", "Confident start", "I in the world", "The world of childhood", "The Path"), and as well as the "Rainbow Music Therapy" and "Joy of Creativity" partial programs, we conclude that the problem 
of choosing, organizing, preparing and conducting holidays and entertainment for children today is not given due attention. And although some programs put forward requirements for a minimum list of holidays and entertainment, their theoretical and methodological analysis, unfortunately, practically does not offer. More fundamentally, this issue is covered by the authors of the "Child in Preschool", "The World of Childhood" programs, and the educational program "The Road" appears to be a practical tool for young preschoolers. It focuses on organizing and conducting not only traditional calendar ritual but also non-traditional holidays: the Feast of Michael, the Feast of Lanterns (late autumn), the Feast of the Father, the Feast of the Birds, the Sunny May, the Feast of the Trinity, the Ivan's Days (Hello, summer!), etc.

Keywords: holidays; an entertainment; an aesthetic education; an artistic and aesthetic education; a musical education of preschoolers.

П остановка проблеми. Сучасний зміст дошкільної освіти передбачає гармонійний і різнобічний розвиток дитини за умови здійснення освітнього процесу на засадах гуманізації та демократизації. Зокрема, Базовий компонент і чинні програми дошкільної освіти орієнтують педагогів на впровадження у практику цілісного підходу до розвитку, виховання й навчання дитини з метою формування життєздатної, свідомої, гармонійної розвиненої, творчої особистості. 3 огляду на це, особливо важливим постає художньо-естетичне виховання дошкільнят, розвиток уних креативних здібностей та формування творчого ставлення до життя, що найбільшою мірою проявляється у результатах їхньої діяльності.

Одним $з$ ефективних та незамінних засобів розвитку дитячої творчості $\epsilon$ мистецтво 3 його розмаїтим, неповторним світом, здатним зворушувати душу, пробуджувати творчу активність, розвивати психічні пізнавальні процеси, виховувати повагу до культурних надбань людства тощо. Саме тому серед пріоритетних напрямів освітньої роботи в сучасному закладі дошкільної освіти (ЗДО) чільне місце посідає забезпечення достатнього рівня художньоестетичного та креативного розвитку особистості у процесі специфічних дитячих видів діяльності.

Аналіз останніх досліджень і публікацій. Зміни, що відбуваються у сучасній дошкільній освіті України передбачають удосконалення не лише освітнього, а й дозвіллєвого процесу у закладах дошкілля. Так, формуючи особистість дошкільника, сучасні вихователі та музичні керівники піклуються про позитивні результати своєї праці, що проявляються в організації, підготовці та проведенні свят та розваг у ЗДО. Ці форми роботи частково увиразнюються в освітніх чинних програмах. Проте, аналіз науковометодичного забезпечення окресленої проблеми свідчить про недостатністю розробленість теоретичних засад укладання сценаріїв свят i розваг для дітей дошкільного віку. Адже, сьогодні до дошкільної сфери висуваються щоразу нові вимоги до підбору не лише традиційних, а й інноваційних свят і розваг та проведення свята- шоу, свята-квестів й інших дозвіллєворелаксаційних дійств для дошкільників. I власне керуючись викликами часу та потребовомотиваційним спрямуванням дітей дошкільного віку у цьому контексті маємо намір здійснити комплексний аналіз програмного забезпечення змісту свят і розваг у ЗДО.

Проблемі свят та розваг у сфері дошкільної освіти України присвячені дослідження Н. Ветлугіної, І. Дубровіної [6], В. Литарь, I. Морозової [10], Т. Науменко, І. Романюк, А. Терещенко, I. Терещенко, В. Харматової, А. Шевчук, С. Шоломович, М. Шуть та ін. Зазначимо, що проблема організації та підготовки до свят і розваг у ЗДО досліджується науковцями в різних аспектах: теоретико-методичний підхід застосовують I. Каспрук [8], Т. Науменко, I. Романюк, А. Шевчук, М. Шуть та ін., прагматичний підхід висвітлюють І. Дубровіна, В. Литарь, І. Мараховська, Н. Степура, І. Морозова, А. Шевчук, М. Шугь та ін. Означена проблематика знаходить відображення у змісті освітніх програм для закладів дошкільної освіти.

Визначення невирішених раніше частин загальної проблеми. Аналіз сучасної науковопедагогічної літератури засвідчує, що в ній відсутне комплексне висвітлення програмового забезпечення свят і розваг у закладах дошкільної освіти, натомість загально подано методичний інструментарій щодо їх проведення в освітній діяльності педагога-дошкільника.

Формулювання мети статті. Метою статті $€$ аналіз сучасних освітніх програм щодо змістових аспектів підготовки та проведення свят і розваг для дітей у закладах дошкільної освіти.

Виклад основного матеріалу. На порозі XXI ст. освітню діяльність сучасних педагогів дошкілля визначають низка законодавчих документів, серед котрих фундаментальним є Базовий компонент дошкільної освіти. Так, у ньому визначено, що в освітній лінії “Дитина у світі культури”, (у рубриці “Музична діяльність”) розглядаються питання організації та підготовки до свят і розваг. Науковці наголошують, що у дошкільника необхідно сформувати уявлення про вокальну й інструментальну музику, основні 
музичні жанри (пісня, марш, танець); уміння охоче слухати й оцінювати музичні твори, перейматися відповідними емоціями й почуттями; виразно співати дитячі пісні; виконувати хороводи, танці, музичні ігри, рухи; відтворювати на дитячих музичних інструментах прості ритмічні мелодії, володіти досвідом індивідуального й колективного виконання твору. Дошкільника також слід навчити виявляти музикальність; елементарні уміння музичної інтерпретації, варіювання, імпровізації; передавати настрій, емоції, почуття через музично-рухову і пісенну творчість, музикування; творчо співпрацювати 3 дітьми й дорослими заради спільного успіху в музичнотеатралізованих розвагах і святах $[1,15]$.

Як бачимо, у базовий документ дошкільної освіти закладено підвалини організації свят і розваг 3 дітьми дошкільного віку, а саме у музичну діяльність, що $\epsilon$ важливою складовою естетичного виховання. Власне тому вся концертна діяльність дошкільників нерозривно пов'язана з нею. Саме музична діяльність впливає на розвиток емоційної сфери дошкільника, формує його загальну культуру, а також відіграє важливу роль в організації, підготовці й проведенні свят і розваг.

Як стверджують фахівці, свята й розваги у ЗДО сприяють розв'язанню освітніх завдань у роботі з дітьми дошкільного віку, оскільки дають їм можливість усвідомити культурний пласт досвіду народу. "Піднятися" до його найвищих моральних і культурних цінностей, а також сформувати різноманітні компетенції, компетентності з метою творчої самореалізації в різних видах діяльності.

Стисло охарактеризуємо значення понять “свято” і “розвага". Термін “свято” (від грец. “еоріз”) уживалося і нині часто вживається для опису особливо піднесеного емоційного стану людини (на рівні душі й серця). Із цим словом асоціюється відчуття приємного, радісного, світлого.

Від лексеми “свято” утворився термін “еортологія" - наука про свято.

Свято - важлива частина життя дитини. Це завжди бажана, очікувана, радісна подія, що привертає іiі увагу насамперед широкими можливостями самореалізації в різних видах діяльності. Свято духовно й культурно збагачує маленьку особистість, сприяє їі успішній соціалізації, широко і щиро відкриває їй особливості та традиції рідного й інших народів, наочно та зрозуміло показує культурні цінності сучасного світу людей, розширює знання дитини про саму себе й навколишній світ. Ця подія спонукає дошкільнят до тотальної творчості, готує до повноцінної продуктивної і креативної діяльності, стає найефективнішим середовищем для самоактуалізації та отримання творчих результатів, приносячи задоволення й переповнюючи їхні душі радістю та позитивними емоціями.

Термін “розвага” означає те, що розвеселяє, розважає людину; заходи з аналогічною метою або місце, де можна повеселитися, розважитися. Розвага - заспокоює, утішає кого-небудь у горі; нещасті; позбавляє сумного настрою, негативних емоцій.

Похідним до розваги є термін “розважати” - звертаючись до кого-небудь із відповідними розмовами, справами тощо, відволікати його від чогось гнітючого, важкого, неприємного, тривожного, підвищувати настрій, розраджувати, дарувати радість.

Відтак, мета дошкільних свят та розваг допомогти дошкільникам пізнати звичаї, традиції, обряди рідного народу, залучити їх до культурної спадщини українського народу, до усвідомлення краси нашої національної обрядовості, прищепити любов до Батьківщини, української мови й пісні.

Отже, свята й розваги, поєднуючи в собі різні види мистецтва, постають яскравими та радісними подіями в житті дітей дошкільного віку, впливають на їх почуття і свідомість $[3,10]$.

Підготовка і проведення дитячого дозвілля значною мірою сприяє моральному вихованню дітей: а) вони об'єднуються спільними переживаннями, що виробляють основи колективізму; б) фольклорні твори, пісні й вірші про Україну, природу, працю формують патріотичні почуття; в) участь у святах і розвагах розвиває у дошкільнят дисциплінованість, культуру поведінки тощо. Святкова атмосфера, краса відповідно оформленого приміщення, вміло підібраний репертуар - це все це важливі фактори естетичного виховання. Участь дітей у святкових співах, іграх, і танцях зміцнює й розвиває дитячий організм, поліпшує координацію рухів. Свята й розваги, які проводяться у ЗДО створюють особливий антураж і приносять дітям яскраве емоційне задоволення та радість.

Аналізуючи чинні програми у контексті нашої статті, ми зауважили відсутність належної уваги до підготовки та проведення свят і розваг у ЗДО. Так, автори регіональної програми "Українське дошкілля" в освітній лінії “Дитина у світі культури” виокремлюють художньо-продуктивну діяльність, що включає образотворчу, музичну, театральну й літературну компоненти, проте жодним чином не увиразнюють проблем свят та розваг у дитячому колективі [2, 199 - 216]. 
Аналогічну ситуацію простежуємо і в чинній програмі “Дитина”, де в освітній діяльності “Дитина у світі культури” передбачені подібні за змістом рубрики: “Образотворча майстерня”, “Музичний калейдоскоп”, “Театральна мозаїка”, “Літературна скринька" [4, 234 - 242], а питання свят та розваг у ЗДО взагалі не висвітлюється.

Тобто, як бачимо, жодна з наведених програм не розглядає проблеми організації та проведення до свят та розваг дітей дошкільного віку. Лише наближено окремі аспекти означеної проблеми відбиваються у рубриці музичної діяльності.

На жаль, замовчує розглядувані нами питання і програма "Впевнений старт". В освітній лінії “Художньо-естетична діяльність" ідеться про формування вміння дітей сприймати твори мистецтва, усвідомлювати їх художню цінність, а також відображати естетичні уявлення i враження у власній творчості. Автори програми наголошують, художньо-естетичний розвиток дитини здійснюється під час реалізації і1ї художньоестетичної діяльності (художньо-літературної, зображувальної, музичної, театральної) і залежить від вікових особливостей та індивідуальних можливостей дитини, її здібностей і нахилів.

На рівень досягнень дитини в означеній діяльності також впливають ставлення батьків до мистецтва, умови художньо-естетичного виховання в родині та закладі дошкільної освіти. Зміст освіти в художній діяльності включає комплекс завдань (освітніх, виховних, розвивальних), мистецького репертуару (орієнтовного вибору художніх творів), тематики мистецької діяльності, а також презентаційні та підсумкові форми організації роботи з дітьми [11,24].

Авторка дошкільної освітньої програми “Соняшник” Л. Калуська акцентує на шести важливих виховних важелях у становленні особистості: фізичному, духовному, моральному, естетичному, емоційному та розумовому (інтелектуальному) [7, 5]. Особливості педагогічної роботи працівників ЗДО висвітлюються у другому розділі програми за назвою "Розвиток і виховання душі й серця", де передбачені такі виховні домінанти: патріотична, соціальна, моральна, естетична, трудова, правова, економічна, екологічна і статева [Там само, 7].

Розділ "Художньо-естетичний розвиток" програми “Соняшник” виокремлює рубрику “Свята та дозвілля”, де йдеться про заохочення дітей до участі у святах та різноманітних формах дозвілля, розвиток позитивних емоцій під час святкових дійств, культуру поведінки під час них [Там само, 39].

Художньо-естетичний розвиток дошкільнят засобами свят і дозвілля включас також і такі напрями: а) залучення дітей до підготовки разом iз дорослими ігор-драматизацій із музичним супроводом; б) навчання сприймати на слух невеликі музичні твори в аудіо запису; в) заохочення до пізнання характерних особливостей різних видів свят та дозвіль; г) залучення до участі у різних видах свят: календарно-обрядових, музичних, літературно-музичних, тематичних, спортивних; концертів, театралізації; д) формування культури й духовності, патріотичних почуттів дошкільнят, емоційно-ціннісного сприймання ними святкових дійств; е) забезпечення позитивного настрою та збагачення емоційно-чугтєвої сфери дитини [7, 81].

На думку Л.В. Калуської, педагогам ЗДО необхідно постійно прищеплювати вихованцям інтерес до змісту й особливостей різних видів свят та дозвіль, а також спонукати дітей до участі в них, що сприяє формуванню культури i духовності, патріотичних почуттів, емоційноціннісного сприймання святкових дійств (старший дошк. вік) [7, 128].

Програма “Я у Світі” в освітній лінії “Світ мистецтва” пропонує характеристику художньоестетичному розвитку дошкільників, зокрема засобами музичного мистецтва. Автори акцентують, що під час сприймання музики дитина проявляє активність, виражає своє ставлення до неї, прагне поділитися враженнями від почутого. У старшому дошкільному віці продовжує зміцнюватися голосовий апарат дошкільняти, розвиватися співочий голос, налагоджуватися вокально-слухова координація. Крім того, диференціюються слухові відчуття, збагачуються виражальні можливості голосу. Дитина долучається до співів, завдяки чому реалізуються іiі музичні й акторські здібності [12, 242].

Беручи активну участь у концертах, святкових ранках, дитина із задоволенням демонструє усім присутнім свої музичні здібності і можливості [Там само, $242-243$ ].

У програмі “Світ дитинства” простежуємо спеціальний розділ “Світ мистецтва", що висвітлює музичну діяльність дошкільнят, після якої подається характеристика свят та розваг для дітей цього віку.

У молодшому дошкільному віці проведення свят та розваг передбачає такі завдання: 1) збагачувати уявлення дітей новими яскравими враженнями, пов'язаними зі змістом знаменних подій; 2) спонукати вихованців до активної участі у різноманітних видах художньої діяльності (читати вірші, співати пісні, танцювати, водити хороводи, проводити веселі ігри тощо), а також музично-ігрових діях; 3) формувати емоційне 
сприйняття веселих сценок настільного, лялькового, пальчикового, тіньового театрів, театру іграшок; 4) заохочувати дошкільнят виконувати прості образні рухи із промовлянням короткого тексту; використовувати навички малювання фарбами для створення потішних персонажів в ігрових ситуаціях; 5) навчати дітей відвовідати на запитання ведучого, наслідувати звуків птахів, тварин тощо; 6) прищеплювати інтерес до музики пісень, танців, веселощів; потребу емоційної реакції на них $[14,48]$.

Серед свят для дітей середнього дошкільного віку автори аналізованої програми виокремлюють Новий рік, День Матері, а серед розваг - різноманітні театри (ляльковий, настільний, пальчиковий, маріонеток, тіньовий, театр іграшок, театр картинок тощо); прослуховування музичних казок (в аудіозапису); невеличкі музичні концерти зусиллями дітей; невеличкі постанови лялькового театру; ігридраматизації; день народження; “мандрівку до казкового лісу”; ігри-забавлянки, “пори року” тощо [Там само, 95 - 96].

Для дітей старшого дошкільного віку програма "Світ дитинства" передбачає святкування Нового Року, Дня Матері, Великодня, Свята Миколая, Випускного ранку. До педагогів ЗДО означена програма висуває низку освітніх завдань при організації дозвілля й розваг дітей: а) вчити сприймати різноманітні розваги (перегляд фільмів, театри, концерти, організовані змагання, гру тощо) як загальну привабливу подію тижня; б) формувати вміння дітей, уважно переглядати певне дійство, вдумливо слухати виступи дорослих; в) спонукати до емоційного відгуку на різні за характером і настроєм розваги; до активності під час підготовки розваг для показу малюкам (лялькові спектаклі, ігри-драматизації, концерти); г) заохочувати до участі в різних розвагах (масові театралізовані події типу карнавалу, спортивні змагання, ігри, вікторини, інсценівки, концерти, конкурси тощо); д) навчати активно застосовувати знання та навички, отримані на різних заняттях, у змаганнях на спритність, витривалість, кмітливість; е) стимулювати до прояву творчості у рухових активних діях тощо $[14,158]$.

У програмі “Дитина в дошкільні роки" виокремлено розділ “Естетичний розвиток”, i спеціальну рубрику “Свята та розваги для дітей раннього, молодшого, середнього та старшого дошкільного віку”. У ранньому дошкільному віці найдоцільніше розпочати ознайомлення дітей 3 елементами музики. Основним показником естетичного розвитку дитини цього віку є вияв емоційної зацікавленості до джерела звуків, веселої, спокійної мелодії.

У трирічному віці дошкільникам у розділі “Естетичний розвиток” пропонується ознайомлення зі світом мистецтва, образотворчої діяльності, музики, свят та розваг.

Так, для дітей раннього дошкільного віку у рубрикації “Свята та розваги” перелічено свята: Нового року, Дня матері та розваги: театр іграшок, ляльковий театр, музичні казки, свято іграшок, концерт старших дітей, “На Гостині в Бабусі-Казки”, ігри-забавлянки тощо [5, 50].

Дітям молодшого дошкільного віку програмою передбачено вже згадувані свята Нового року, Дня матері, а також численні розваги: різноманітні лялькові театри, настільний, пальчиковий театри, театр іграшок, фланелеграф; тіньовий театр; концерт старших дітей “Казкова Скринька", “Чарівний мішечок”, день народження, ігри-забавлянки; музичні казки.

В освітній лінії “Музика” для дітей середнього дошкільного віку пропонується відзначення Нового року, Дня матері, а також низка розваг: різноманітні театри (ляльковий, настільний, пальчиковий, маріонеток, тіньовий, театр іграшок, театр картинок тощо); прослуховування музичних казок (у грамзапису); невеличкі музичні концерти силами дітей; невеличкі постанови лялькового театру; ігри-драматизації; день народження, “Мандрівка до казкового лісу”; ігри-забавлянки; "Пори року” тощо [5, 124].

Розділ “Естетичний розвиток дитини” в освітній лінії “Свята та розваги” увиразнює свята й розваги для дітей старшого дошкільного віку: Новий рік, День Матері, випускний ранок; різноманітні театри (ляльковий, настільний, пальчиковий, маріонеток, тіньовий, театр іграшок, театр картинок тощо), підготовлені дорослими або силами дітей “Пори року”, “Зелений вогник”, “Ми - юні пожежники”, День казок, інсценівки, драматизації пісень, День іменинників, музично-літературні концерти, конкурси, виступ дитячого оркестру, фольклорні свята, спортивні свята (розваги), вечори гумору [Там само, 186].

На наш погляд, найбільш фундаментально до організації та підготовки свят і розваг дошкільнят увиразнюють автори програми “Стежина" (за вальдорфською системою). Вони виокремили рубрику “Музично-рухова діяльність”, яка, на нашу думку, є найбільш наближеною до тематики нашої розвідки. Особливо деталізовано організацію й підготовку до свят у ЗДО.

Позитивним $\epsilon$ те, що у програмі вперше висвітлюється на теоретичному рівні важливість 
свят та розваг загалом, а також конкретно для дошкілля. Наголошується, що свята у дошкільному закладі - це особлива форма дитячого переживання, що допомагає вихованцям усвідомити своє місце у природі та космосі. Святкові заходи, за своєю сутністю близькі до ігор, органічно “вплітаються" в життєдіяльність дітей і стають повноцінною та привабливою іiі частиною, емоційно насичуючи духовний світ дошкільнят своїм особливим змістом. Окрім днів народження та інших локальних традиційних свят, значне місце відводиться святкуванню подій кругообігу року, що виражається в образносимволічній, співзвучній дитячому світосприйняттю формі. Особливо акцентується на естетичному сприйнятті дітьми явищ природи (схід сонця, зорі, вітер, снігопад, дощ та ін.). Організаторам необхідно прагнути, щоб свято не набуло характеру формального заходу й не втратило своєрідності, емоційної насиченості та душевності.

“Стежина” закликає педагогів ЗДО при виборі свят орієнтуватися на традиційні місцеві звичаї, самобутні національні особливості музичної культури, культурно-регіональні традиції, обряди, адаптуючи їх до специфіки дошкільного закладу. Основною будь-яких свят є їх ритмічний характер. Життя наших предків було ритмічним, найменше порушення його призводило до тривоги, хвилювань, метушні. Мудрий народ усе передбачив, створивши для всіх випадків життя свої специфічні обряди та звичаї, з якими діти ознайомлюються на святах. Традиційними для українських дошкільних закладів є святкування днів народження дітей, Святого Миколая, відзначення Нового Року, Різдва, Великодня, Дня матері (Свята весни), Свята урожаю (осені), випуску дітей до школи. У закладах дошкільної освіти, котрі працюють за вальдорфською системою, практикуються ще й такі святкові дійства: Свято Михаїла, Свято Ліхтариків (пізня осінь), Свято батька, Свято птахів, Сонячний травень, свято Трійці, Іванові дні (Здрастуй, літо!) та ін. [15, $167-168]$.

Кожне свято річного кола пов'язане 3 певною динамікою, настроєм: осіннє свято Михаїла - це мужність, сила; Різдво - спокій, внутрішня рівновага; Свято матері, чи Свято весни, це радість, захват, благоговіння; Свято випуску до школи - радість спільно із сумом, Великдень відродження життя після смерті, коли жартують, водять хороводи, розфарбовують яйця, печуть у групі маленькі пасочки, саджають на ділянку пророслі жито і пшеницю.

Особливо неповторним для дітей є Свято ліхтариків, яке немовби “переносить” у казкову чарівну країну, де так багато світла й тепла, що ними можна поділитися з іншими. Адже темної й похмурої осінньої пори все здається сірим i безрадісним; ллють дощі, день стає коротким, хочеться тепла, світла, хочеться зігріти душу й відчути затишок. Усе навкруги занурюється в темряву та освітлюється лише маленькими паперовими ліхтариками, які $є$ носіями-символами світла й тепла, що випромінюють дитячі серця (до речі, такі ліхтарики діти роблять самі).

Восени усі в ЗДО готуються до ярмарку: власноруч майструють вироби (це зазвичай ляльки з тканини, зваляні з вовни гномики, свічки, подушки, ялинкові прикраси і багато іншого). Саморобні печива і тортики діти готують разом 3 вихователями та батьками $[15,168]$.

Головне свято для кожної дитини - іiї день народження. Тоді розповідають історію про іменинника та його батьків, співають пісень, читають вірші, дарують власноруч виготовлені подарунки. Мами вишивають зірку на спеціальному плащі іменинника, готують цікаву розповідь про те, яким був їхній малюк у дитинстві, згадують кумедні історії, які з ним траплялися, показують сімейні фотографії. Таке свято $€$ надзвичайно важливим переживанням для батьків, адже вони бачать як інших дітей цікавить усе, що пов'язане з їхнім малюком, отримують задоволення від зворушливого, безпосереднього спілкування з друзями своєї дитини.

Вальдорфська педагогіка культивує ідеї співробітництва батьків, дітей та вихователів. Батьки, які є активними учасниками всього життя дошкільного закладу, беруть безпосередньо участь у підготовці до будь-якого свята $[15,169]$.

Підготовка до свята, за програмою “Стежина", передбачає 3 боку педагогів реалізацію низки завдань, а саме: 1) вчасно помічати й підтримувати ініціативу дітей щодо підготовки до свята в таких проявах, як участь у розробці сценарію, виготовлення костюмів, обговорення особливостей окремих епізодів свята; 2) сприяти щирості вияву почуттів, підтримувати фантазування вихованців; 3) зберігати позитивну, доброзичливуатмосферубезпосередності, прихильності один до одного; 4) демонструвати власний піднесений настрій і спонукати дітей до цього; 5) заохочувати дошкільнят до імпровізації під час свят; 6) навчати отримувати естетичне задоволення від святкового дійства.

Крім того, вихователям надзвичайно важливо налаштувати дітей на відчуття свята, усвідомлення урочистості, особливості події, що зумовлює піднесений настрій усіх учасників заходу, а також організовувати поступове 
ознайомлення дітей із культурно-побутовими традиціями, вивчати щедрівки, колядки, пісні, вірші, хороводи, готувати подарунки $[15,175]$.

Автори програми “Стежина" закликають дошкільних педагогів виготовляти разом з дітьми просторово-об'ємні композиції (кругові панорами), що відображають сутність свята (на столі, полиці чи підлозі розміщують зроблених із натуральних та природних матеріалів маленьких лялечок, тварин, рослин, композиція 3 яких символізує святкову подію), розглядати композиції, заохочувати щось доповнити чи змінити у них.

Необхідно навчати дітей проговорювати назви музичних інструментів, музичних творів; використовувати в мові елементарні музичні поняття: пісня, танок, динаміка, тривалість, темп, ритм, інструментальна й вокальна музика, виконавці, жанри; назви танців тощо. Не менш важливо ініціювати розмови про музичні твори, музичні інструменти, танці, свята тощо.

Програма "Стежина" радить вихователям ЗДО постійно уникати упродовж підготовки до свята тривалих та нудних тренувань, дратівливості, зайвої метушні, страхів, стресу; формальної підготовки концертної програми “на показ”, оскільки це відбирає багато часу й позитивних емоцій. Наголошується на необхідності залучати до підготовки свята й участі в ньому всіх: і дітей, i батьків, і вихователів - разом облаштовувати групову кімнату, залу, майданчик, використовуючи заздалегідь зроблені прикраси $[15,176]$.

Сьогодні у вітчизняній освітній канві функціонує низка парціальних (додаткових) програм для розвитку творчих та художньоестетичних здібностей дошкільнят. Серед них для нашої розвідки становлять цінність дві з них: “Радість творчості" (програма художньоестетичного розвитку дітей раннього та дошкільного віку) і “Веселкова музикотерапія" (програма оздоровчо-освітньої роботи $з$ дітьми старшого дошкільного віку), хоча й вони досить поверхово висвітлюють аспект нашого аналізу.

Програма “Радість творчості” містить рубрику “Краса музики”, що виокремлює основні освітні завдання педагогів, починаючи з раннього дошкільного віку, а саме:

- заохочення дітей до підспівування і співів, до виконання простих музичних вправ i танцювальних рухів, гри на дитячих музичних інструментах, участі у музичних дидактичних іграх та міні-концертах, святкових ранках;

- розвиток слуху та музичних здібностей вихованців;

- виховання емоційної чутливості дошкільнят та їхніх перших музичних уподобань, естетичних смаків.

Відтак, найважливішим показником мистецької компетентності молодших дошкільників за цією програмою є їх активна участь (чи прагнення до неї) у музичних іграх та святкових виставах [13, 25]. У старшому дошкільному віці означеними критеріями постають індивідуальні музичні здібності дітей, їх участь у міні-концертах, святкових ранках; уміння імпровізувати й отримувати естетичну насолоду від самостійної музичної діяльності $[13,36]$.

Проблему свят та розваг розглядає оздоровчоосвітня програма "Веселкова музикотерапія". У ній із сумом констатується прикрий факт функціонування у сучасних ЗДО т. зв. “концертнопоказової моделі музичного виховання”, де мають місце безкінечні нудні репетиції, коли від маленьких виконавців вимагають справжньої дорослої акторської майстерності. Зазвичай, у повсякденній практиці, педагоги просто підбирають відповідний музичний репертуар і розучують його з дітьми до показового чергового виступу. Тому такий “перегин” у бік підготовки дошкільнят до концертно-розважального свята (шоу) для дорослих порушує головне завдання музичного виховання в цьому віці: гармонізацію емоційної сфери дітей, яка відіграє важливу роль у становленні особистості, розвитку іiі вищих психічних функцій, регуляції поведінки, формуванні духовної культури $[9,6]$.

Висновки. Отже, проаналізувавши програмне забезпечення сучасної вітчизняної дошкільної освіти щодо об'єкта нашої розвідки, доходимо висновку, що проблемі вибору, організації, підготовки та проведення свят і розваг дітей сьогодні не надається належної уваги. I хоча окремі програми висувають вимоги до мінімального переліку свят та розваг, їх теоретико-методичного аналізу, на жаль, практично не пропонують. Більш грунтовно це питання висвітлюють автори програм “Дитина в дошкільні роки”, “Світ дитинства”, а практично рятівним документом для молодих дошкільних педагогів постає лише освітня чинна програма “Стежина”. Глибоке дослідження шляхів і засобів організації свят та розваг в умовах сучасних вітчизняних закладів дошкільної освіти вважаємо перспективою подальших наукових розвідок.

\section{ЛІТЕРАТУРА}

1. Базовий компонент дошкільної освіти / наук. кер.: А.М. Богуш, дійсний член НАПН України, проф, д-р пед. наук; авт. кол-в: Богуш А. М., Бєлєнька Г. В., Богініч [та ін.]. Київ, 2012. 26 с.

2. Білан О.І. Програма розвитку дитини дошкільного 
віку "Українське дошкілля" / за заг. ред. О.В. Низковської. Тернопіль, 2017. 256 с.

3. Городиська В., Береза С. “Свята та розваги в ЗДО”: тексти лекцій. Дрогобич, 2018. 235 с.

4. Дитина : освітня програма для дітей від двох до семи років / наук. кер. проекту В.О. Огнев'юк; авт. кол. Г.В. Бєлєнька, О.Л. Богініч, Н.І. Богданець-Білоскаленко [та ін.]; наук. ред. Г.В. Бєлєнька, М.А. Машовець. Київ, 2016.304 c.

5. Дитина в дошкільні роки : комплексна додаткова освітня програма / автор. колектив; наук. керівник К.Л. Крутій. Запоріжжя, 2011. 188 с.

6. Дубровіна І.В. Організація свят та розваг у дошкільних навчальних закладах : навч.-метод. посіб. Біла Церква, 2012. 166 с.

7. Калуська Л.В. Комплексна програма розвитку, навчання та виховання дітей дошкільного віку “Соняшник”.Тернопіль, 2014. 144 с.

8. Каспрук І. Свята і розваги в дошкільному навчальному закладі : метод. посіб. Львів, 2015.100 с.

9. Малашевська I.А., Демидова С.К. Програма оздоровчо-освітньої роботи 3 дітьми старшого дошкільного віку "Веселкова музикотерапія". Тернопіль. 2015. 44 с.

10. Морозова І.П. Свята та розваги в ДНЗ. Харків, 2017. $240 \mathrm{c}$.

11. Освітня програма “Впевнений старт” для дітей старшого дошкільного віку / [Н.В. Гавриш, Т.В. Панасюк, Т.О. Піроженко, О.С. Рогозянський, О.Ю. Хартман, А.С. Шевчук]; за заг. наук. ред. Т.О. Піроженко. Київ, 2017. 80 с.

12. Програма розвитку дитини дошкільного віку “ $Я$ у Світі” (нова редакція). У 2-х ч. - Ч.ІІ. - Від трьох до шести (семи) років / О.П. Аксьонова, А.М. Аніщук., Л.В. Артемова та ін.; наук. кер. О.Л. Кононко. Київ, 2014. 452 с.

13. Програма художньо-естетичного розвитку дітей раннього та дошкільного віку "Радість творчості" / Р. М. Борщ, Д. В. Самойлик. Тернопіль, 2013. 72 с.

14. Світ дитинства : комплексна освітня програма для дошкільних навчальних закладів / упоряд. : О.М. Байєр, Л.В. Батліна, А.М. Богуш та ін.; наук. кер. акад. А.М. Богуш; за заг. ред. Л.В. Батліної. Тернопіль, $2015.200 \mathrm{c}$.

15. Стежина : комплексна альтернативна освітня програма для дошкільних навчальних закладів, що працюють за вальдорфською педагогікою : авториупорядники А.М. Гончаренко, Н.М. Дятленко. Київ, $2014.223 \mathrm{c}$.

\section{REFERENCES}

1. Bohush, A. (2012). Bazovyi komponent doshkilnoi osvity [The basic component of preschool education]. Kyiv, 26 p. [in Ukrainian].

2. Bilan, O.I. (2017). Prohrama rozvytku dytyny doshkilnoho viku "Ukrainske doshkillia" [Preschool child development program "Ukrainian Preschool"]. Ternopil : Mandrivets Publ., 256 p. [in Ukrainian].

3. Horodyska, V.\& Bereza, S. (2018). "Sviata ta rozvahy $v$ zakladakh doshkilnoi osvity" : teksty lektsii ["Holidays and entertainment in preschool establishments": lectures]. Drohobych, 235 p. [in Ukrainian].
4. Ohnev'iuk, V.O. (2016). Dytyna: osvitnia prohrama dlia ditei vid dvokh do semy rokiv [Child: An educational program for children from two to seven years old]. Kyiv, 304 p. [in Ukrainian].

5. Krutii, K.L. (2011). Dytyna v doshkilni roky : kompleksna dodatkova osvitnia prohrama [A child in pre-school years: a comprehensive additional educational program]. Zaporizhzhia, 188 p. [in Ukrainian].

6. Dubrovina, I.V. (2012). Orhanizatsiia sviat ta rozvah $u$ doshkilnykh navchalnykh zakladakh : navchalnometodychnyi posibnyk [Organization of holidays and entertainments in preschool educational institutions: educational-methodical manual]. Belaya Tserkov, $166 \mathrm{p}$. [in Ukrainian].

7. Kaluska, L.V. (2014). Kompleksna prohrama rozvytku, navchannia ta vykhovannia ditei doshkilnoho viku "Soniashnyk" [Integrated program of development, training and upbringing of preschool children "Sunflower"]. Ternopil, 144 p. [in Ukrainian].

8. Kaspruk, I. (2015). Sviata i rozvahy v doshkilnomu navchalnomu zakladi : metodychnyi posibnyk [Holidays and entertainment in a preschool educational institution: methodical manual]. Lviv, 100 p. [in Ukrainian].

9. Malashevska, I.A. (2015). Prohrama ozdorovchoosvitnoi roboty $z$ ditmy starshoho doshkilnoho viku "Veselkova muzykoterapiia" [Health-education program with children of the senior preschool age "Rainbow Music Therapy']. Ternopil, 44 p. [in Ukrainian].

10. Morozova, I.P. (2017). Sviata ta rozvahy v doshkilnomu navchalnomu zakladi [Holidays and entertainment at a preschool institution]. Kharkiv, 240 p. [in Ukrainian].

11. Havrysh, N.V. (2017). Osvitnia prohrama "Vpevnenyi start" dlia ditei starshoho doshkilnoho viku [Educational program "Confident Start" for children of the senior preschool age]. Kyiv, 80 p. [in Ukrainian].

12. Aksonova, O.P., Anishchuk, A.M. \& Artemova, L.V. (2014). Prohrama rozvytku dytyny doshkilnoho viku "Ia u Sviti" (nova redaktsiia) [The program of development of a child of preschool age "I am in the World" (new edition)]. Kyiv, 452 p. [in Ukrainian].

13. Borshch, R.M. \& Samoilyk, D.V. (2013). Prohrama khudozhno-estetychnoho rozvytku ditei rannoho ta doshkilnoho viku "Radist tvorchosti" [Program of artistic and aesthetic development of children of early and preschool age "Joy of creativity"]. Ternopil, 72 p. [in Ukrainian].

14. Bohush, A. (2015). Svit dytynstva : kompleksna osvitnia prohrama dlia doshkilnykh navchalnykh zakladiv [The world of childhood: a comprehensive educational program for preschool educational institutions]. Ternopil, 200 p. [in Ukrainian].

15. Honcharenko, A.M. \& Diatlenko, N.M. (2014). Stezhyna : kompleksna alternatyvna osvitnia prohrama dlia doshkilnykh navchalnykh zakladiv, shcho pratsiuiut za valdorfskoiu pedahohikoiu [Path: Complex alternative educational program for preschool educational institutions working on Waldorfpedagogy]. Kyiv,223 p. [in Ukrainian].

Стаття надійшла до редакції 22.02.2019 